\title{
PERBEDAAN KARAKTERISTIK KIMIA DAN DAYA CERNA PATI TEPUNG JAGUNG DAN TEPUNG KECAMBAH JAGUNG (Zea mays L.)
}

\author{
Willem Kurniawan Lombu ${ }^{1}$, Ni Wayan Wisaniyasa ${ }^{2}$, A.A.I. Sri Wiadnyani ${ }^{2}$ \\ ${ }^{1}$ Mahasiswa Jurusan Ilmu dan Teknologi Pangan Fakultas Teknologi Pertanian UNUD \\ ${ }^{2}$ Dosen Jurusan Ilmu dan Teknologi Pangan Fakultas Teknologi Pertanian UNUD \\ Email : willson.last@gmail.com
}

\begin{abstract}
This study aims to determine the difference of characteristic and starch digestibility of germinated and ungerminated flour. This study used randomized complete design (RCD) three repeated. The corn germinated for 36 hours. Corn germinated flour and ungerminated flour were evaluated directly of the chemical composition of the flour content, moisture content, ash content, protein, fat, carbohydrates, fiber, starch content and starch digestibility. The results showed the corn germinated flour has increased of moisture content from $9.66 \%$ into $10.38 \%$, increased of protein into $7.22 \%$ into $8.45 \%$, increased of fiber content from $2.28 \%$ into $2.79 \%$ and increased of starch digestibility from $57.04 \%$ into $62.43 \%$. While were the decreased fat content from $5.17 \%$ into $4.76 \%$, decreased of carbohydrate from $75.41 \%$ into $73.89 \%$ and decreased of starch content from $76.10 \%$ into $69.40 \%$. The treatmented has no effect for the flour content decreased from $41.40 \%$ into $40.36 \%$ and ash content decreased from $2.52 \%$ into $2.51 \%$. Germinated increased starch digestibility and changed the character of corn flour.
\end{abstract}

Kata kunci : starch digestibility, corn, cornstarch germinated flour

\section{PENDAHULUAN}

Salah satu bahan pangan alternatif yang berpotensi untuk dikembangkan adalah jagung (Zea mays L.). Jagung merupakan sumber karbohidrat yang dapat berfungsi sebagai sumber pangan alternatif pengganti beras dan terigu. Permintaan terhadap jagung cenderung meningkat dari tahun ke tahun baik untuk konsumsi masyarakat maupun untuk industri makanan. Salah satu proses yang dapat dimanfaatkan dalam pengembangan potensi jagung ialah dengan pembuatan tepung.

Sebagai sumber karbohidrat utama, jagung juga mengandung protein, vitamin dan mineral yang dibutuhkan oleh tubuh. Jagung mengandung energi sebesar 149 kalori/100 g untuk jagung lokal dan 114,2 kalori/100 g untuk jagung manis (Suarni dan Yasin, 2011). Salah satu upaya untuk meningkatkan kualitas dari jagung adalah melalui proses perkecambahan. Perkecambahan telah diketahui sebagai proses yang tidak mahal dan teknologi yang efektif dalam meningkatkan kualitas kacang-kacangan dan biji - bijian. Perkecambahan dapat menyebabkan perubahan pada kandungan nutrisi karena adanya respirasi aerobik dan metabolisme biokimia.

Tepung merupakan alternatif produk setengah jadi yang disarankan karena lebih tahan disimpan, dapat dibuat komposit, difortifikasi, dibentuk dan lebih cepat diolah sesuai dengan tuntutan kehidupan modern. Untuk meningkatkan kualitas dari tepung dapat dilakukan dengan proses perkecambahan pada biji jagung. Perkecambahan akan mengalami rangkaian perubahan-perubahan morfologi, fisiologi dan biokoimia, sehingga proses perkecambahan akan meningkatkan daya cerna serta memperbaiki kualitas nutrisi pada jagung. Tepung kecambah jagung ini nanti dapat dimanfaatkan dalam pembuatan produk makanan pendamping air susu ibu (MP-ASI). 
Memasuki usia 6 bulan keatas, kandungan gizi yang terdapat pada ASI tidak lagi mencukupi sementara kebutuhan enrgi bayi meningkat $24-30 \%$ dibanding kebutuhan saat usia 3-5 bulan (Anon, 2000). Kandungan gizi yang dijadikan standar diantaranya karbohidrat, protein, lemak, vitamin (A, C, dan D), serta mineral (natrium, kalsium, zat besi, seng, dan yodium). Sedangkan menurut Adriani dan Wirjatmadi (2012), MP-ASI sebaiknya memiliki nilai energi dan protein yang tinggi, mengandung vitamin dan mineral dalam jumlah yang cukup, dapat dicerna oleh anak, harganya terjangkau bagi masyarakat.

Penelitian ini bertujuan untuk mengetahui pengaruh perkecambahan jagung (Zea mays L.) terhadap karakteristik dan daya cerna pati tepung kecambah jagung (Zea mays L.), serta untuk mengetahui karakteristik kimia dan daya cerna pati tepung jagung dan tepung kecambah jagung (Zea mays $\quad$ L.) yang dihasilkan. Penelitian menggunakan rancangan acak lengkap (RAL) dengan 2 perlakuan dan 3 kali ulangan. Perlakuan pertama biji jagung tidak dikecambahkan dan perlakuan kedua biji jagung dikecambahkan.

\section{BAHAN DAN METODE}

\section{Tempat dan Waktu Penelitian}

Penelitian ini dilaksanakan di Laboratorium Pengolahan Pangan dan Laboratorium Analisis Pangan Fakultas Teknologi Pertanian Universitas Udayana, Jalan PB. Sudirman, Denpasar. Penelitian ini dilaksanakan dari bulan Juni sampai dengan bulan Agustus 2017, sedangkan untuk pengujian daya cerna pati dilakukan di
Laboratorium Pangan dan Gizi Fakultas Teknologi Pertanian Universitas Gadjah Mada.

\section{Alat dan Bahan}

Bahan-bahan yang digunakan dalam melaksanakan penelitian ini terdiri dari bahan baku, dan bahan kimia. Bahan baku terdiri dari jagung varietas Arjuna dengan tingkat kematangan sekitar umur 2,5 bulan atau ditandai dengan rambut pada jagung bewarna kecoklatan. Jagung diperoleh dari pedagang di sekitar daerah Sanur Denpasar. Bahan kimia yang digunakan dalam melakukan analisis proksimat meliputi $\mathrm{H}_{2} \mathrm{SO}_{4}, \mathrm{NaOH}, \mathrm{HCl}$, Heksan, $\mathrm{K}_{2} \mathrm{SO}_{4}$, alkohol 96\%, tablet Kjeldahl, asam borat, indikator PP, larutan enzim $\propto$-amilase, buffer Na-Fosfat.

Alat-alat yang digunakan dalam melaksanakan penelitian ini antara lain waskom, panci, penggilingan, timbangan analitik, oven, kertas saring, erlenmeyer, cawan porselin, tabung reaksi, batang pengaduk, eksikator, corong, pipet tetes, labu takar, buret, muffle, pendingin balik, destilator, spektrofotometer, gelas ukur, gelas beker, pipet volume, labu kjeldahl, soxhlet, waterbath, dan peralatan analisis kadar abu.

\section{Rancangan Percobaan}

Rancangan yang digunakan pada penelitian ini adalah Rancangan Acak Lengkap (RAL) dengan perlakuan tanpa perkecambahan dan perkecambahan.

$$
\begin{array}{ll}
\mathrm{F} 1 & =\text { Tanpa perkecambahan } \\
\mathrm{F} 2 & =\text { Perkecambahan jagung } 36 \mathrm{jam} \\
& \text { Masing-masing perlakuan diulang }
\end{array}
$$
sebanyak 3 kali, untuk membedakan karakteristik kimia dan daya cerna pati antara 
tepung jagung yang tidak dikecambahkan dengan tepung jagung yang dikecambahkan dilakukan dengan uji T-test (Stell and Torrie, 1995).

\section{Pelaksanaan Penelitian}

\section{a. Proses Pembuatan Kecambah Jagung}

Proses pembuatan kecambah jagung dapat dilihat pada Gambar 1.

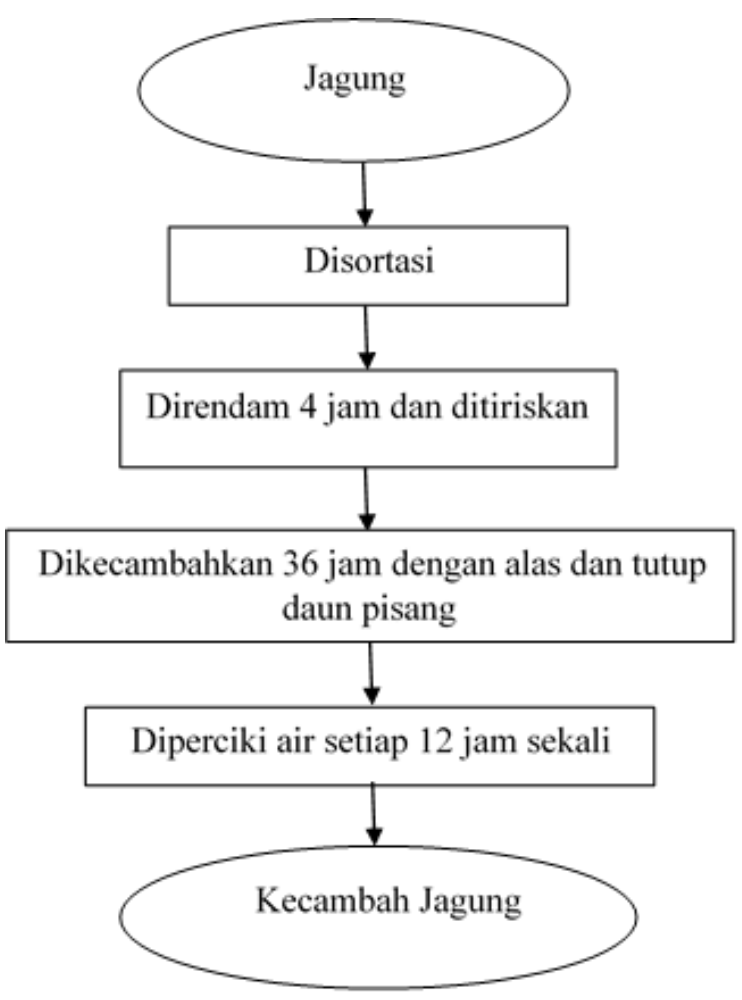

Gambar 1 . Proses pembuatan kecambah jagung

(Aminah dan Hersoelisyoritni, 2012 yang dimodifikasi)

Mula-mula jagung disortasi, ditimbang sebanyak $100 \mathrm{~g}$, kemudian direndam selama 4 jam dengan perbandingan antara biji jagung dan air 1:2, kemudian ditiriskan. Selanjutnya biji jagung dikecambahkan pada keranjang pelastik berlubang dengan alas daun pisang yang dipotong kecil-kecil dan ditutup bagian atasnya dengan daun pisang, lalu didiamkan selama 36 jam dan setiap 12 jam diperciki dengan air.

\section{b. Proses Pembuatan Tepung Jagung dan Tepung Kecambah Jagung}

Jagung dan Kecambah Jagung dioven selama 20 jam dengan suhu $50^{\circ} \mathrm{C}$. Jagung yang sudah kering setelah dioven kemudian digiling sampai halus dengan menggunakan blender. Biji jagung yang sudah hancur kemudian diayak dengan menggunakan ayakan berukuran 60 mesh. 


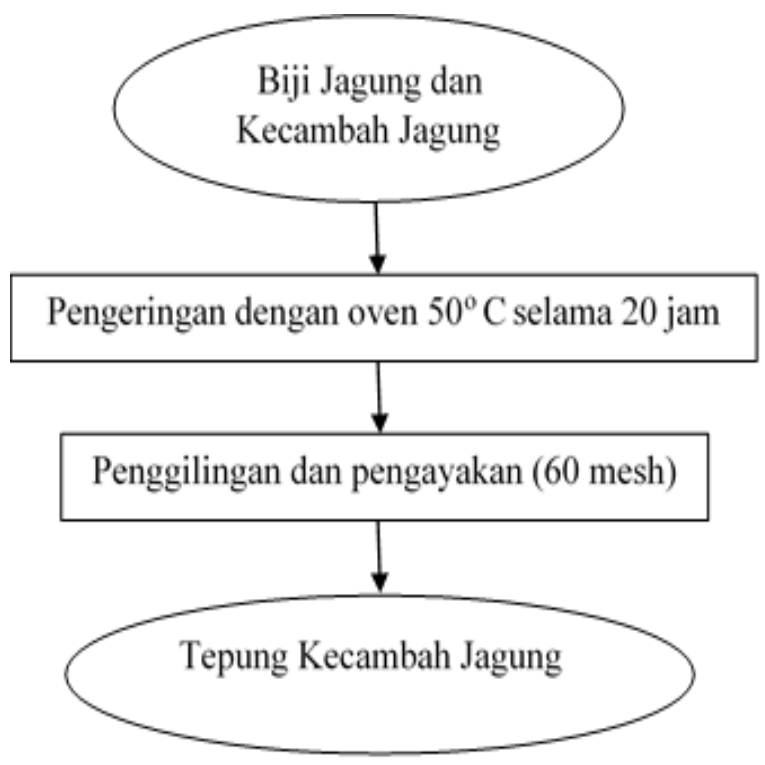

Gambar 2 . Proses pembuatan tepung jagung dan tepung kecambah jagung (Aminah dan Hersoelisyoritni, 2012 yang dimodifikasi)

\section{Variabel yang Diamati}

Dalam penelitian ini adapun variabel yang diamati yaitu : rendemen, analisis kadar air dilakukan dengan menggunakan metode pengeringan (Sudarmadji et al., 1997), kadar abu dilakukan dengan menggunakan metode pengabuan (Sudarmadji et al., 1997), kadar protein dilakukan dengan menggunakan metode Mikro-Kjeldahl (Sudarmadji et al., 1997), kadar lemak dilakukan dengan menggunakan metode Soxhlet (Sudarmadji et al., 1997), kadar karbohidrat dengan analisa Carbohydrate by different (Sudarmadji et al., 1997), serat kasar dengan metode hidrolisis asam basa (Sudarmadji et al., 1997), kadar pati dilakukan dengan metode spektofotometri
(Sudarmadji, 1997), daya cerna pati dapat dilakukan secara in vitro (Muchtadi, 1992).

\section{HASIL DAN PEMBAHASAN}

Hasil menunjukkan bahwa perlakuan tepung jagung dan tepung kecambah jagung berpengaruh sangat nyata terhadap kadar air, protein, lemak, karbohidrat, serat kasar, pati, dan daya cerna pati, namun berpengaruh tidak nyata terhadap rendemen dan kadar abu. Data rendemen, kadar air, kadar abu, protein, lemak, karbohidrat, serat kasar, pati dan daya cerna pati dapat dilihat pada tabel dibawah. Perbedaan Karakter Kimia dan Daya Cerna Pati Tepung Jagung dan Tepung Kecambah Jagung dapat dilihat pada Tabel 1. 
Tabel 1. Perbedaan Karakter Kimia dan Daya Cerna Pati Tepung Jagung dan Tepung Kecambah Jagung

\begin{tabular}{lccc}
\hline \multicolumn{1}{c}{ Parameter } & $\begin{array}{c}\text { Tepung Jagung } \\
(\%)\end{array}$ & $\begin{array}{c}\text { Tepung Kecambah } \\
\text { Jagung }(\%)\end{array}$ & Hasil Uji T - tes \\
\hline Rendemen & 41,40 & 40,36 & NS \\
Kadar Air & 9,66 & 10,38 & $* *$ \\
Kadar Abu & 2,52 & 2,51 & NS \\
Protein & 7,22 & 8,45 & $* *$ \\
Lemak & 5,17 & 4,76 & $* *$ \\
Karbohidrat & 75,41 & 73,89 & $* *$ \\
Serat Kasar & 2,28 & 2,79 & $* *$ \\
Pati & 76,10 & 69,40 & $* *$ \\
Daya Cerna Pati & 57,04 & 62,43 & $* *$ \\
\hline Ket : ${ }^{* *}$ berbeda sangat nyata & & &
\end{tabular}

\section{Rendemen}

Rendemen tepung jagung sebesar $41,39 \%$ dan rendemen tepung kecambah jagung sebesar 40,40\%. Tabel 1 menunjukkan rendemen antara tepung jagung dan tepung kecambah jagung tidak nyata.

\section{Kadar Air}

Kadar air tepung jagung sebesar 9,66\%, sedangkan kadar air tepung kecambah jagung sebesar 10,38\%. Hasil uji $\mathrm{T}$ - test, menunjukkan bahwa kadar air tepung jagung berbeda sangat nyata dengan kadar air tepung kecambah jagung. Hal ini disebabkan karena sebelum perkecambahan biji jagung direndam dalam air selama 4 jam, dan saat proses perkecambahan berlangsung, pada kecambah dilakukan proses penyiraman setiap 12 jam sekali. Terjadinya peningkatan kadar air disebabkan karena selama perkecambahan terjadi penyerapan air oleh kecambah.

\section{Kadar Abu}

Kadar abu tepung jagung sebesar 2,52\%, sedangkan kadar abu tepung jagung sebesar 2,51\%. Hasil uji T-test menunjukkan bahwa perlakuan perkecambahan tidak berpengaruh terhadap kadar abu $(\mathrm{P}>0,05)$ tepung kecambah jagung. Besarnya kadar abu produk pangan menunjukkan besarnya kandungan mineral bahan tersebut.

\section{Protein}

Protein tepung jagung sebesar $7,22 \%$, sedangkan kadar protein tepung kecambah jagung sebesar 8,45\%. Hasil uji T-test, menunjukkan bahwa perlakuan perkecambahan berpengaruh sangat nyata terhadap kadar protein tepung $(\mathrm{P}<0,01)$. Peningkatan kadar protein tepung kecambah disebabkan karena terjadinya pembentukan asam - asam amino essensial ataupun terbentuknya asam amino baru yang tidak ada sebelumnya yang merupakan senyawa 
penyusun dari protein. Protein diperlukan untuk pertumbuhan kecambah jagung selama proses perkecambahan. Hasil ini sesuai dengan pernyataan Lopez dan Escobedo (1989) yang menyatakan bahwa perkecambahan akan meningkatkan kandungan protein Amaranth seeds. Pada penelitian Wisaniyasa dan Suter (2015) perkecambahan juga terbukti meningkatkan kadar protein kacang merah.

\section{Lemak}

Hasil penelitian menunjukkan bahwa proses perkecambahan berpengaruh sangat nyata terhadap kadar lemak tepung kecambah. Dari tabel 1 terlihat bahwa hasil uji T-test menunjukkan kadar lemak tepung jagung berbeda sangat nyata dengan kadar lemak tepung kecambah jagung. Kadar lemak tepung jagung sebesar 5,17\% sedangkan kadar lemak tepung kecambah jagung 4,76\%. Lemak digunakan sebagai sumber energi untuk pertumbuhan dan perkembangan benih baru, maupun untuk sintesis vitamin - vitamin sehingga mengalami peningkatan selama perkecambahan. Proses perkecambahan akan meningkatkan protein dan vitamin, sedangkan kandungan lemaknya mengalami penurunan. Hal ini didukung dengan pernyataan Satyanti (2001) dimana penurunan kadar lemak terjadi karena selama proses perkecambahan berlangsung, terjadi peningkatan enzim lipase. Lemak juga dihidrolisis menjadi asam-asam lemak yang lebih bebas, sehingga lebih mudah dicerna dan diserap oleh saluran pencernaan (Winarno, 1980).

\section{Karbohidrat}

Dari Tabel 1 terlihat bahwa hasil uji T-test menunjukkan kadar karbohidrat tepung jagung berbeda sangat nyata dengan kadar karbohidrat tepung kecambah jagung. Kadar karbohidrat tepung jagung sebesar 75,41\%, sedangkan kadar karbohidrat tepung kecambah jagung sebesar 73,89\%.

Penurunan kadar karbohidrat disebabkan karena karbohidrat merupakan persediaan bahan makanan yang dibutuhkan kecambah untuk pertumbuhan. Satyanti (2001) menyatakan jika perkecambahan akan meningkatkan aktivitas enzim amilase yang berperan untuk mendegradasi karbohidrat pada bahan. Enzim amilase terdiri dari 2 yaitu $\alpha$-amilase dan $\beta$-amilase. Enzim $\alpha$-amilase akan memecah pati menjadi glukosa dan dekstrin, sedangkan $\beta$-amilase akan memecah pati menjadi maltosa dan dekstrin, yang nantinya akan diubah lagi untuk menjadi energi. Perkecambahan akan menguraikan polisakarida menjadi karbohidrat sederhana, sehingga mengalami penurunan nilai kandungan karbohidrat pada bahan .

\section{Serat Kasar}

Tabel 1 menunjukkan serat kasar tepung jagung berbeda sangat nyata dengan serat kasar tepung kecambah jagung. Serat kasar pada tepung jagung sebesar 2,28\%, sedangkan serat kasar tepung kecambah jagung sebesar $2,79 \%$.

Menurut Anuchita dan Nattawa (2010) kandungan serat pada kecambah bergantung pada tipe dan varietas bahan. Peningkatan kandungan serat pada kecambah dipengaruhi 
oleh sintesis stuktural karbohidrat seperti selulosa dan hemiselulosa yamg merupakan komponen terbesar pada bahan (Syed, 2011). Perkecambahan dapat meningkatkan kandungan serat kasar pada bahan (Lopez dan Escobedo, 1989). Uchegbu dan Amulu (2015) juga membuktikan bahwa perkecambahan mampu meningkatkan kadar serat Afrika Yam Bean.

\section{Kadar Pati}

Hasil penelitian menunjukkan bahwa proses perkecambahan berpengaruh sangat nyata terhadap kadar pati tepung kecambah. Dari tabel 1 terlihat tepung jagung sebesar $76,10 \%$, sedangkan kadar pati tepung kecambah jagung sebesar $69,40 \%$.

Saat perkecambahan pati tidak langsung ditanslokasikan menuju titik tumbuh benih karena ukuran molekulnya sangat besar dan tidak dapat larut pada air, sehingga pati dipecah telebih dahulu oleh enzim amilase. Asam giberelat yang dihasilkan saat proses perkecambahan akan mendukung proses pembentukan enzim amilase yang akan memecah karbohidarat menjadi bentuk yang terlarut dan dapat diangkut. Aktivitas enzim amilase akan meningkat seiring lama perkecambahan berlangsung, sehingga pati akan terus mengalami pengurangan (Kiranawati, 2002).

\section{Daya Cerna Pati}

Hasil penelitian menunjukkan bahwa proses perkecambahan berpengaruh sangat nyata terhadap daya cerna pati tepung kecambah. Dari Tabel 1 terlihat bahwa hasil uji T-test menunjukkan daya cerna pati tepung jagung berbeda sangat nyata dengan daya cerna pati tepung kecambah jagung. Daya cerna pati tepung jagung sebesar 57,04\%, sedangkan daya cerna pati tepung kecambah jagung sebesar $62,43 \%$. Daya cerna pati adalah kemampuan enzim pemecah pati dalam menghidrolisis pati menjadi unit-unit yang lebih kecil (gula-gula yang lebih sederhana). Semakin tinggi daya cerna suatu pati, maka akan semakin banyak pati yang dihidrolisis dalam waktu tertentu.

Zainal (2013) menyatakan pada saat perkecambahan imbisisi air akan merangsang aktivitas giberelin yang diperlukan untuk mengaktivasi enzim amilase. Enzim ini selanjutnya akan bekerja dengan mengkatalis proses perubahan cadangan makanan, dimana pati akan menjadi gula yang akan digunakan sebagai sumber energi untuk pertumbuhan sel hidup baru. Hasil penelitiannya menunjukkan bahwa daya cerna pati kacang merah dan kacang buncis hitam meningkat seiring lama waktu perkecambahan. Hasil penelitian ini didukung oleh pernyataan Kamil (1979) yang menyatakan pada perkecambahan terjadi proses degradasi senyawa kompleks yang bersifat tidak larut menjadi senyawa yang lebih sederhana yang bersifat larut dalam air seperti glukosa dan asam amino yang akan diangkut untuk keperluan pertumbuhan kecambah baru.

\section{KESIMPULAN DAN SARAN}

\section{Kesimpulan}

Berdasarkan hasil penelitian dapat disimpulkan Perkecambahan pada jagung sangat berpengaruh terhadap kadar air, karbohidrat, 
protein, serat kasar, kadar pati dan daya cerna pati. Karakter tepung jagung adalah kadar air 9,66\%, kadar abu 2,52\%, protein 7,22\%, lemak $5,17 \%$, karbohidrat 75,41\%, serat kasar 2,28\%, kadar pati $76,10 \%$ dan daya cerna pati $57,04 \%$ sedangkan tepung kecambah jagung adalah kadar air 10,38\%, kadar abu 2,51\%, protein $8,45 \%$, lemak 4,76\%, karbohidrat 73,89\%, serat kasar 2,79\%, kadar pati $69,40 \%$ dan daya cerna pati $62,43 \%$. Proses perkecambahan dapat meningkatkan daya cerna pati pada tepung dan mengubah karakter kimianya.

\section{Saran}

Berdasarkan hasil penelitian dapat disarankan : Untuk meningkatkan kualitas karakteristik jagung, bisa dilakukan dengan proses perkecambahan dan Perlu dilakukan pengujian daya simpan tepung kecambah jagung dan produk-produk olahannya.

\section{DAFTAR PUSTAKA}

Adriani, M dan B. Wirjatmadi. 2012. Peranan Gizi dalam Siklus Kehidupan. Kencana Prenada Media Group. Jakarta.

Aminah, S. dan W. Hersoelistyorini. 2012. Karakteristik Kimia Tepung Kecambah Serealia dan Kacangkacangan dengan Variasi Blanching. Universitas Muhammadiyah Semarang. Semarang. Seminar Hasil- Hasil Penelitian LPPM UNIMUS 2012. ISBN: 978-602-18809-0-6

Anonimous. 2000. Complementery Feeding : Family Foods for Breastfed Children. Department of Nutrition and Development. World Health Organization. Geneva

Anuchita Moongngarm, N. S. 2010. Comporison of Chemical
Compositions and Bioactive Compound of Germinated Rough Rice and Brown Rice. Food Chemistry 782-788

Kamil J. 1979. Teknologi Benih I. Bandung : Angkasa.

Kiranawati, T. M. 2002. Evaluasi Mutu Susu Pra Kecambah Biji Kacang Tunggak. Thesis Program Pasca Sarjana Jurusan Teknologi Hasil Pertanian. Universitas Brawijaya. Malang.

Lopez, O. P. dan M. Escobedo. 1989. Germination of Amaranth Seeds : Effect of Nutrient Composition and Color. Journal of Food Science 54:761-762

Muchtadi D. 1992. Evaluasi Nilai Gizi Pangan. PAU Pangan dan Gizi Intitut Pertanian Bogor. Bogor

Satyanti. 2001. Peningkatan Kandungan Tokoferol Dalam Potensi Antioksidatif Mie Instant dengan Suplementasi Menggunakan Pasta Kecambah Kacang Hijau. Thesis Pascasarjana. Universitas Gadjah Mada. Yogyakarta

Suarni dan M. Yasin. 2011. Jagung Sebagai Sumber Pangan Fungsional. Iptek Tanaman Pangan vol. 6 no $1-2011$

Sudarmadji, S., H. Bambang dan Suhardi. 1997. Prosedur Analisa Untuk Bahan Makanan dan Pertanian. Liberty. Yogyakarta.

Stell, R.G.D. and J.H. Torrie. 1995. Prinsip dan Prosedur Statistika Suatu Pendekatan Biometrik. PT. Gramedia Pustaka Utama, Jakarta. (diterjemahkan oleh B. Sumantri)

Syed, A. S. A. Z. 2011. Effect of SproutingTime On Biochemical and Nutritional Qualities of Mungbean Varieties. Journal of Agricultural Research, 5092.

Uchegbu, N.N., and F.N. Amulu. 2015. Effect of Germination on Proximate, Available Phenol and Flavonoid Content, and Antioxidant Activities of African Yam Bean (Sphenostylis stenocarpa). International Journal of Biological, Biomolecular, Agricultural, Food and Biotechnological Engineering Vol:9, No:1: 106-9 
Winarno, F.G., S.S. Endang dan A.B. Ahza. 1980. Mempelajari Pengaruh Proses Perkecambahan Biji-bijian terhadap Sifat Fisik dan Kimia Rendemen Tepung. Bul. FTDCIPN, Mei 1980, Bogor

Wisaniyasa, W.N dan I.K. Suter. 2015. Kajian Sifat Fungsional dan Kimia Tepung Kecambah Kacang Merah
(Pahseolus vulgaris L.) dan Aplikasinya Menjadi Flakes. Hibah Unggulan Program Studi. Ilmu dan Teknologi Pangan. Universitas Udayana. Bali

Zainal, A. R. 2013. Amilase Pada Kecambah Kacang Merah dan Kacang Bunci Hitam (Phaseolus vulgaris L.). Fakultas MIPA. Universitas Lampung 